\title{
Hysteresis vs. Natural Rate of Unemployment: One, the Other, or Both?
}

Ferit Kula, Alper Aslan*

\section{Abstract:}

This paper re-examines the empirical validity of the hysteresis hypothesis in unemployment rates by education level in 17 OECD countries. To this end, for an unbalanced panel, we employed Pesaran's Cross-Sectional Dependence (CD) and Cross-Sectionally Augmented ADF (CADF) tests. Our empirical findings provide evidence favorable to the non-stationarity of unemployment rates according to levels of primary and secondary education attainment in total unemployment, and therefore the existence of hysteresis for these levels of education. There is no evidence, however, of hysteresis for unemployment rates by tertiary education.

Keywords: Cross-Sectional Dependence, Hysteresis, Unit Root

JEL: C23, E24

DOI: $10.2478 / \mathrm{v} 10033-010-0009-0$

\section{Introduction}

There has been an intense and lively academic and political debate on unemployment in world economies during the last 25 years, notably for European economies. Two major hypotheses on the time series properties of unemployment can be distinguished: the natural rate hypothesis (NRH) and the hysteresis hypothesis $(\mathrm{HH})$. The $\mathrm{NRH}$ characterizes unemployment dynamics as a mean reverting process, which means that the unemployment rate tends to revert to its equilibrium in the long run. On the other hand, $\mathrm{HH}$ states that cyclical fluctuations have permanent effects on the level of unemployment; therefore, the level of unemployment can be characterized as a non-stationary process.

If the $\mathrm{HH}$ holds, then the unemployment dynamic tends to be a non-stationary or unit root process that does not return to its long run equilibrium. This has significant policy implications. High levels of unemployment, if left unattended by the government, may persist and continue to be a serious problem. If the unemployed are unemployed for such a long time, they lose valuable skills, grow incompetent and hence remain unemployable. Thus, unemployment has negative impacts on economic growth, social stability, individual self-confidence, income distribution and individual morale or altitude. Due to its importance, widespread empirical literature has developed around the topic of unemployment $\mathrm{HH}$ (Liew et al. 2009). On the other hand, if unemployment follows the $\mathrm{I}(0)$ process, the effects of the shock will merely be transitory, thus rendering the need for policy action less mandatory since unemployment will eventually return to its equilibrium level. The I(0) process has commonly been referred to $\mathrm{NRH}$.

Despite a burgeoning literature on testing $\mathrm{HH}$ and NRH (e.g., Blanchard and Summers, 1986; Mitchell, 1993; Song and $\mathrm{Wu}, 1998$; Leon-Ledesma, 2002; Chang et al., 2005) through time series and panel data unit-root

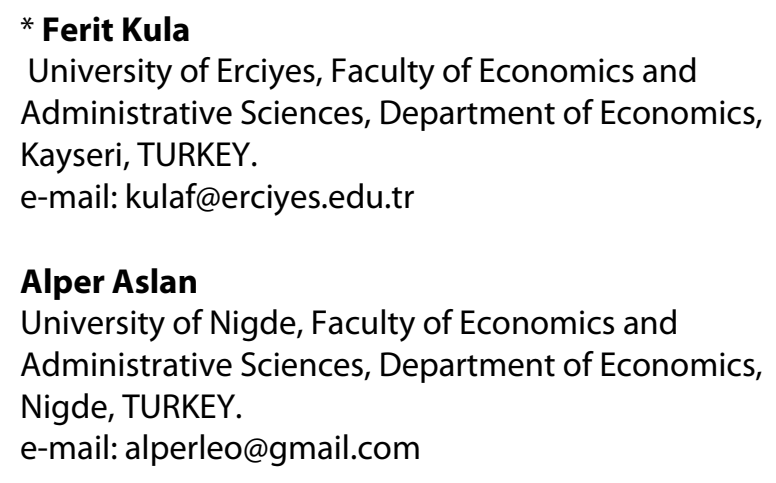

University of Erciyes, Faculty of Economics and Administrative Sciences, Department of Economics, Kayseri, TURKEY.

e-mail:kulaf@erciyes.edu.tr

\section{Alper Aslan}

University of Nigde, Faculty of Economics and Administrative Sciences, Department of Economics, Nigde, TURKEY.

e-mail: alperleo@gmail.com 
methodology, there are still some methodological debates associated with the empirical literature.

First of all, the dynamics of the aggregate unemployment rate is neglected in many studies (Gustavsson and Osterholm, 2006). Due to discouragedworker and added-workers effects, particularly in less skilled workers, new empirical works have started to turn their attention to examining variations in the labor force participation rate and employment rate ${ }^{1}$ (e.g., Gustavsson and Osterholm, 2007; Madsen et al., 2008). One other issue that has been addressed in time-series analyses of $\mathrm{HH}$ is whether there has been a structural break in the unemployment series. Several studies illustrate that structural breaks could provide an explanation for hysteresis or persistence in the equilibrium rate of unemployment (e.g., Papell et al. 2000; Summers, 2003; Lee and Chang, 2008). The last methodological problem is that cross-sectional dependencies are not taken into account in panel data analysis of $\mathrm{HH}$ (e.g., Camarero et al., 2006; Berger and Everaert, 2008). This problem is stated explicitly by Christopoulos and Ledesma (2007). They applied a battery of second-generation panel unit root tests that allow for cross-sectional correlation. Although the data set was the same used in Ledesma's (2002), contrary to Ledesma's findings, the hypothesis of unemployment hysteresis in the EU is rejected. The study shows that, contrary to previous empirical literature, hysteresis does not characterize EU unemployment.

In this paper, we re-examine the informational value of unemployment rates in studies of hysteresis from disaggregated perspectives. In this paper, second generation panel data unit root methodology is employed to investigate the differences between unemployment among workers categorized by their level of educational attainment for 17 OECD countries. This approach allows us to abstract from changes in the composition of the unemployed labor force by focusing on particular educational groups while accounting for the presence of cross-sectional dependence.

The paper is organized as follows: Section II presents the data used. The econometric techniques and the empirical results are discussed in Section III. The final section concludes the paper.

\footnotetext{
${ }^{1}$ Labor force skill level and expansion of the educational system may affect the employability of workers and hence the cyclicality of both employment and unemployment rates (Murphy and Topel, 1997; Keane and Prasad, 1993; Hoynes, 1999; Gustavsson and Osterholm, 2007; Camarero et al., 2008).
}

\section{Data}

This study uses unemployment indicators including the percentage distribution of a country's total unemployed according to level of educational attainment. Data for both indicators were collected from the International Labour Organization-ILO (2007) and the World Bank's World Development Indicators (WDI) online database. The major classifications used in the databases are unemployment with primary education (UPE), unemployment with secondary education (USE) and unemployment with tertiary education (UTE). The sample is an unbalanced panel data that comprises 17 OECD countries with a time length that varies between 12 to 27 years. For details about data, please see the Appendix.

\section{Methodology and Analysis}

A traditional testing procedure to empirically examine $\mathrm{HH}$ is to apply unit root tests on the unemployment rate. Because hysteresis is consistent with non-stationary unemployment rates, unit root tests provide a convenient methodological framework. Starting with Levin and Lin (1992), much work has also been done on testing for unit roots in panels, including papers by Maddala and $\mathrm{Wu}$ (1999), Choi (2001), Im et al., (2003) and others. In addition, as shown in two simulation studies by Banerjee et al. (2004a, 2004b) if panel members are crosscorrelated, all these tests experience strong size distortions and restricted power. For this reason, panel unit root tests relaxing the assumption of cross-sectional independence have recently been proposed in the literature by Choi (2002), Bai and Ng (2003), Moon and Perron (2003), Pesaran (2003), Phillips and Sul (2003) and Peseran (2005).

To check if our sample is characterized by crosssection dependence, Pesaran's cross-sectional dependence test is applied.

Pesaran (2004) presents a simple cross-sectional dependence test $(C D)$ that can be applied to both balance and unbalanced panels. The test is based on the average of pair-wise correlation coefficients $\left(\hat{\sigma}^{i j}\right)$ of the residuals obtained from the individual augmented Dickey-Fuller (ADF) regression. The CD statistics for an unbalanced panel is computed as:

$$
C D=\sqrt{\frac{2}{N(N-1)}}\left(\sum_{i=1}^{N} \sum_{j=i+1}^{N} \sqrt{T_{i j}} \hat{\sigma}_{i j}\right)
$$


Table 1 contains CD statistics that obtain residuals from ADF estimations with intercept and linear trend regression. The hypothesis of zero cross-section correlation is rejected for all series at the $1 \%$-level of significance.

\begin{tabular}{|l|c|c|c|}
\hline Test results & UPE & USE & UTE \\
\hline CD statistic & 17.171 & 22.647 & 38.377 \\
$\mathrm{p}$-value & $(0.000)$ & $(0.000)$ & $(0.000)$ \\
\hline
\end{tabular}

Notes: The CD statistic is asymptotically normally distributed. The $p$ values refer to a two-sided test.

Table 1: Pesaran's cross-sectional dependence test

A very important issue in panel unit root and also cointegration tests is cross-sectional dependence. In fact, the properties of all panel unit root and cointegration tests are based on the assumption that the error terms are not cross-correlated. Therefore, cross-sectional dependence should be taken into account.

To this end, second generation panel unit root tests can be adopted that reject the cross-sectional independence, including those of Phillips and Sul (2003) and Pesaran (2005), Bai and Ng (2004), Moon and Perron (2004). In this paper, we consider the test defined in Pesaran (2005) to be helpful for small panels².

Pesaran (2005) proposes the following ADF regression with the cross-section averages of lagged levels and first differences of the data:

$$
\begin{aligned}
\Delta y_{i t}=c_{i 0}+c_{i} t & +\beta_{i} y_{i, t-1}+\sum_{j=1}^{p} \gamma_{i j} \Delta y_{i, t-j} \\
& +\varphi_{i} \bar{y}_{t-1}+\sum_{j=0}^{p} \eta_{i j} \Delta \bar{y}_{t-j}+u_{i t}
\end{aligned}
$$

where $\bar{y}_{t}=\sum_{i=1}^{N} y_{i t} / N$. The t-ratio of $\beta_{i}$ is used as the test statistic for a unit root and is called the crosssectionally augmented ADF (CADF) statistic. Its critical values have been generated by Monte Carlo and are tabulated in Pesaran (2005). The results reported are the $Z(N, T)$ version, which is normally distributed under the null hypothesis of the unit root defined as:

\footnotetext{
${ }^{2}$ Because Peseran's method does not require the direct estimation of idiosyncratic components from the data, it can be beneficial for small panels where estimation of factors is difficult (Moon and Peron, 2007).
}

$Z(N, T)=\frac{1}{\sqrt{N}} \sum_{1}^{N} \phi^{-1}\left(P_{i T}\right)$

where $P_{i T}$ is the $\mathrm{p}$-value corresponding to the unit root test of the $i^{\text {th }}$ individual cross-section unit.

Table 2 shows the CADF statistics for the UPE, USE and UTE series within our samples. The null hypothesis of a unit root cannot be rejected for the UPE and USE series with all lag specifications. But we are able to reject the null hypothesis of a unit root for the UTE series with 0 and 1 lag specifications.

\begin{tabular}{|c|c|c|c|}
\hline $\mathbf{p}$ & UPE & USE & UTE \\
\hline 0 & -0.161 & -1.283 & $-2.696^{*}$ \\
& $(0.436)$ & $(0.100)$ & $(0.004)$ \\
\hline \multirow{2}{*}{1} & 0.880 & 0.992 & $-1.545^{* *}$ \\
& $(0.810)$ & $(0.839)$ & $(0.061)$ \\
\hline \multirow{2}{*}{2} & 3.856 & 2.717 & 1.836 \\
& $(1.000)$ & $(0.997)$ & $(0.967)$ \\
\hline
\end{tabular}

Note: $\mathrm{p}$ is average lags. $\mathrm{p}$-values in brackets. ${ }^{*}$ and ${ }^{* *}$ indicates significance at the $1 \%$ and $\% 10$ levels, respectively.

Table 2: Pesaran's CADF test

Our results from CADF statistics are consistent with the HH for the UPE and USE series. However, the empirical evidence does not indicate HH for the UTE series for our sample. These results indicate that shocks have permanent effects on unemployment for those with lower levels of educational attainment, while unemployment for those with a higher level of educational attainment tends to revert to its equilibrium in the long run after a shock.

\section{Conclusion}

We have applied CADF unit root tests to unemployment rates by educational attainment in the total unemployment for 17 OECD countries during the period 1980-2007 with unbalanced panel data. After controlling for educational attainment, we find significant differences between unemployment rates. More specifically, we can conclude that the evidence is favorable to the non-stationary of unemployment rates by primary and secondary education attainment in total unemployment, and therefore the existence of hysteresis in primary and secondary education.

However, we also find that there is no evidence of hysteresis for unemployment rates by tertiary education in total unemployment. The results also point to the 
importance of considering some degree of heterogeneity with educational differences in labour markets. $[$.

\section{References}

Bai, J. and Ng, S. (2004) "A PANIC attack on unit roots and cointegration", Econometrica, 72, 1127-1177.

Banerjee, A., M. Marcellino and C. Osbat, 2004a, "Some Cautions on the Use of Panel Methods for Integrated Series of Macroeconomic Data", The Econometrics Journal, 7, 322-340.

Banerjee, A., M. Marcellino and C. Osbat, 2004b, "Testing for PPP: Should we use Panel Methods?" Empirical Economics, 30, 77-91

Berger, T. and Everaert, G. (2008) "A replication note on unemployment in the OECD since the 1960s: what do we know?" Empirical Economics,

Blanchard, O.J. and Summers, L.H. (1986) "Hysteresis and the European unemployment problem", in NBER Macroeconomics Annual. MIT Press, Cambridge, MA.

Camarero, M., Carrion-i-Silvestre, J. L. and Tamarit, C. (2006), "Testing for hysteresis in unemployment in OECD countries: new evidence using stationarity panel tests with breaks", Oxford Bulletin of Economics and Statistics, 68, 167-182.

Camarero, M., Carrion-i-Silvestre, J. L. and Tamarit, C. (2008), "Unemployment hysteresis in transition countries: evidence using stationarity panel tests with breaks", Review of Development Economics, 12, 620-635.

Christopoulos D., and M. Leon-Ledesma (2007), "Unemployment hysteresis in EU countries: what do we really know about it?" Journal of Economic Studies, 34 (2), 80-89.

Chang, T., Nieh, K.C., Wei, C.C., (2005) "An empirical note on testing hysteresis in unemployment for ten European countries: panel SURADF approach", Applied Economics Letters, 12, 881-886.

Chang, Y. (2002), "Nonlinear IV unit root tests in panels with crosssectional dependence", Journal of Econometrics, 110, 261-292.

Choi, I. (2001) "Unit root tests for panel data", Journal of International Money Finance, 20, 249-272.

Choi, I. (2002) Combination unit root tests for cross-sectionally correlated panels, Mimeo, Hong Kong University of Science and Technology.

Gustavsson, M. and Osterholm, P. (2006) "The informational value of unemployment statistics: a note on the time series properties of participation rates", Economics Letters, 92, 428-433.

Gustavsson, M. and Osterholm, P. (2007) "Does unemployment hysteresis equal employment hysteresis?" The Economic Record, 83, 159-173.

Hoynes, Hilary. (1999) "The employment, earnings, and income of less skilled workers over the business cycle". NBER Working Paper 7188.

ILO (2007), Key indicators of the labour market (KILM), Fifth edition. (CD-ROM version)

Im, K. S., Pesaran, M. H. and Shin, Y. (2003) "Testing for unit roots in heterogeneous panels", Journal of Econometrics, 115, 53-74.

Keane, M. and Prasad, E. (1993) "Skill levels and the cyclical variability of employment, hours, and wages." IMF Staff Papers. 40: 711743.

Leon-Ledesma, M.A. (2002) "Unemployment hysteresis in the U.S. states and the EU: a panel approach", Bulletin of Economic Research, 54, 95-103.

Levin A. and Lin C.F. (1992) "Unit root tests in panel data: asymptotic and finite-sample properties", U. C. San Diego Discussion Paper 92-23
Liew , V.K.S, Chia, R. C-J and Puah, C.H. (2009) "Does Hysteresis in Unemployment Occur in OECD Countries? Evidence from Parametric and Non-Parametric Panel Unit Roots Tests", University Library of Munich, Germany in its series MPRA Paper with number 99

Maddala, G. S. and Wu, S. (1999) "A comparative study of unit root tests with panel data and a new simple test", Oxford Bulletin of Economics and Statistics, special issue, 631-52.

Madsen, J., Mishra, V. and Smyth, R. (2008) "Are labour force participation rates non-stationary? Evidence from 130 years for G7 countries", Australian Economic Papers, 47, 166-189.

Mitchell, W.F. (1993) "Testing for unit roots and persistence in OECD unemployment rates", Applied Econometrics, 25, 1489-1501.

Moon, H. R. and Perron, B. (2007) "An empirical analysis of nonstationarity in a panel of interest rates with factors", Journal of Applied Econometrics, 22, 383-400.

Murphy, K.M. and Topel, R.H. (1997) "Unemployment and nonemployment", American Economic Review, 87, 295-300.

Papel D, C.J. Murray and H. Ghiblawi (2000), "The structure of unemployment", The Review of Economics and Statistics 82, 309-315.

Pesaran, M.H. (2004) "General diagnostic tests for cross section dependence in panels", CESifoWorking Paper No. 1229.

Pesaran, M.H. (2005) "A simple panel unit root test in the presence of cross-section dependence", Cambridge Working Papers in Economics No.0346, University of Cambridge.

Phillips, P.C.B. and Sul, D. (2003) "Dynamic panel estimation and homogeneity testing under cross section dependence", Econometrics Journal, 6, 217-259.

Song, F.M. and Wu, Y. (1998) "Hysteresis unemployment: evidence from OECD countries", The Quarterly Review of Economics and Finance, $38,181-192$

Summers, L., (2003) "Cyclical dynamics in the new economy", Journal of Policy Modeling 25, 525-530.

\section{Appendix}

\begin{tabular}{|l|c|c|}
\hline Country & Age & Data availability \\
\hline Australia & $15+$ & $1989-2007$ \\
\hline Austria & $15+$ & $1985-2007$ \\
\hline Belgium & $15+$ & $1994-2007$ \\
\hline Canada & $15+$ & $1980-2007$ \\
\hline Denmark & $15-66$ & $1994-2007$ \\
\hline Finland & $15-77$ & $1995-2007$ \\
\hline Germany & $15+$ & $1996-2007$ \\
\hline Italy & $15+$ & $1993-2007$ \\
\hline Japan & $15+$ & $1987-2007$ \\
\hline Netherlands & $15-64$ & $1995-2007$ \\
\hline New Zealand & $15+$ & $1990-2007$ \\
\hline Norway & $16-74$ & $1996-2007$ \\
\hline Spain & $16+$ & $1980-2007$ \\
\hline Sweden & $16-64$ & $1987-2007$ \\
\hline Switzerland & $15+$ & $1991-2007$ \\
\hline United Kingdom & $15-64$ & $1987-2007$ \\
\hline United States & $25+$ & $1994-2007$ \\
\hline
\end{tabular}

